\title{
INCIDENCE OF AEROBIC AND ANAEROBIC SPOREFORMERS AND THERMOPHILIC FUNGI IN CONDENSED MILK IN ASSIUT CITY
}

(With 5 Tables)

\author{
By
}

EMAN KORASHY and M.S. SABREEN*

* Dept, of Food Hygiene, Fac. Vet. Med., Assiut University. (Rccoived at 26/6/2001)

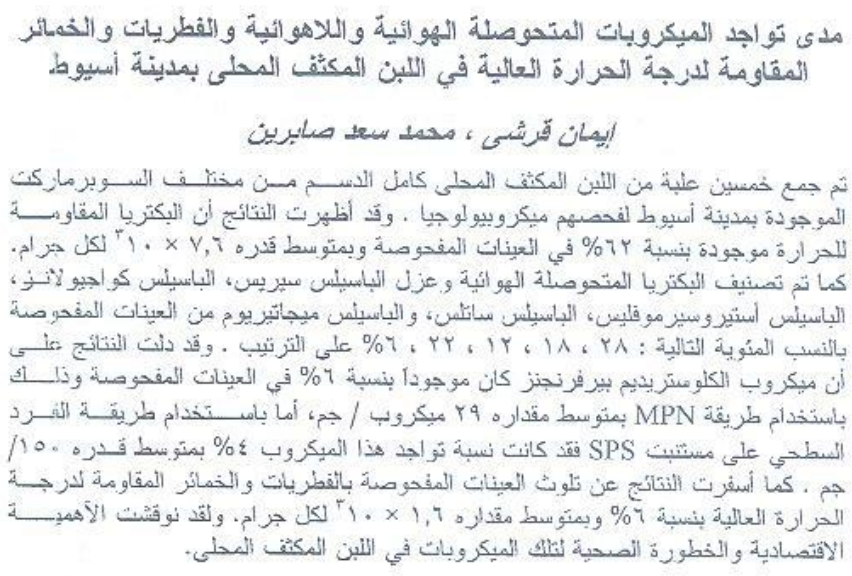

\section{SUMMARY}

Fifty random samples of full cream sweetened condensed milk cans were collected from different supermarkets in Assiut City for microbiological evaluation. Thermoduric bacteria could be detected in $62 \%$ of the condensed milk samples, with an average count of $7.6 \times 10^{3} / \mathrm{g}$. B, cereus, B. coagulans, B. stcarothermophilus, B. subtilis and B. megaterium could be isolated from the examined samples with incidence percentages of $28,18,12,22$ and $6 \%$, respectively. Cl. perfringens could be detected 
of $28,18,12,22$ and $6 \%$, respectively. $\mathrm{Cl}$. perfringens could be detected in $6 \%$ of the condensed milk samples using MPN technique, with an average value of $2.9 \times 10^{1} / \mathrm{g}$, while on SPS agar this organism was present in $4 \%$ of the examined samples, with an average of $1.5 \times 10^{2} / \mathrm{g}$. On the other hand, $3(6 \%)$ of condensed milk samples were positive for thermophilic fungi, with an average number of $1.6 \times 10^{3} / \mathrm{g}$. The economic significance and the public health importance of these organisms were discussed.

Key words: Condensed milk, Aerobic \& Anaerobic Sporeformers, Fungi.

\section{INTRODUCTION}

Condensed milk is a concentrated milk product resulting from the evaporation of a considerable portion of the water content of milk. Sweetened condensed milk is prescrved by the addition of sugar to prevent or retard spoilage. Major advantages lie in a considerable reduction in transport and storage costs as a result of the reduction in bulk and convenience of use during formulation, there is also a significant extension of the ambient temperature storage life. Full cream swectened condensed milk contains not less than $28 \%$ of milk solids and not less than $8.5 \%$ of milk fat. It is nourishing, delicious, easily digestible and a good source of energy. Condensed milk may be used undiluted in coffee, tea and other beverages, as a topping for fruits or ice cream, or just straight from the tin. It is also used for the preparation of fortified low-fat milks, confectionery, bakery products, infant formulas and other food items.

On the other hand, the initial microflora are those of the raw milks from which the condensed milks are made. Sugar used in such product may contain sporeforming bacteria, and yeasts and moulds (Lampert, 1987 and Milner, 1995). In general, sweetened condensed milk is not a sterile product, and the various methods of heat treatment used are not adequate to kill sporeforming bacteria, and further processing and handling usually contribute a variety of microorganisms, besides the sugar levels employed permit some types to grow if other conditions are favourable. Enough oxygen may be present in the head space of an incompletely filled, or poorly sealed container, to permit the growth of organisms able to tolerate the high osmotic pressure of the product. 
These organisms may be associated with defects in condensed milk such as thickening, acid production, proteolysis and lipolysis. As well as, moulds, which form hard, coloured bodies or buttons, are sometimes found on the surface of the product, and such milk often is bitter or rancid. Occasionally, gas forms, usually caused by sugar-fermenting yeasts (ICMSF, 1980; Lampert, 1987; Tudor and Board, 1993 and Varnam and Sutherland, 1994). Furthermore, Bacillus cereus and Clostridium perfringens are widely recognized as a principal causes of human food poisoning of bacterial origin (Iversen et al., 1982; Anon, 1990 and (Granum el al., 1993). In addition, some moulds are capable of producing toxic metabolites known as mycotoxins, such as aflatoxins which are known as carcinogens (Massey et al., 1995; Markaki and Melissari, 1997 and Li et al., 2000).

Therefore, the purpose of this investigation is to study the incidence and level of contamination of aerobic and anaerobic sporeformers and thermophilic fungi in condensed milk sold in Assiut City.

\section{MATERIAL and METHODS}

lifty random samples of full cream sweetened condensed milk cans were collected from different supermarkets in Assiut City for microbiological evaluation. Preparation and handling of collected samples were done according to standard methods (A.P.H.A., 1992). The prepared samples were examined for the following:

I- Thermoduric bacterial count: The technique recommended by A.P.H.A. (1992) using standard plate count agar was made. Separate colonies were identified according to Kramer et al. (1982) and Parry et al. (1983).

2 - Enumeration of $\mathrm{Cl}$. perfringens: Was performed by using two techniques, the first, MPN technique using lactose sulphite (IS) broth as described by Beerens et al. (1982). The second, direct plating technique using sulphite polymyxin sulfadiazine (SPS) agar as recommended by Angelotti et al. (1962). Moreover, suspected colonies were picked up for further confirmation according to Mead et al. (1981)

3- Thermophilic fungi count: Malt extract agar with antibiotic \{chlorotetracyclin $\mathrm{Hcl}$ and chloramphinicol\} (Speck, 1976) was employed. The inoculated plates were incubated for 7-10 days at $55^{\circ} \mathrm{C}$, and thermophilic yeasts and moulds were counted. 


\section{RESULTS}

The results were recorded in Tables $1-5$.

Table 1: Statistical analytical results of thermoduric bacterial count/g of the examined condensed milk samples.

\begin{tabular}{|c|c|c|c|c|c|}
\hline \multirow{2}{*}{$\begin{array}{c}\text { No. of } \\
\text { examined } \\
\text { Samples }\end{array}$} & \multicolumn{2}{|c|}{$\begin{array}{c}\text { Positive } \\
\text { samples }\end{array}$} & \multicolumn{4}{|c|}{ Count/g } \\
\cline { 2 - 6 } & No. & $\%$ & Min. & Max. & Average \\
\hline 50 & 31 & 62 & $1.0 \times 10^{2}$ & $6.0 \times 10^{4}$ & $7.6 \times 10^{3}$ \\
\hline
\end{tabular}

Table 2: Occurrence of aerobic sporeforming bacteria isolated from the examined condensed milk samples.

\begin{tabular}{|l|c|c|}
\hline \multirow{2}{*}{\multicolumn{1}{c}{ Bacillus species }} & \multicolumn{2}{c|}{ Positive samples } \\
\cline { 2 - 3 } & No./50 & $\%$ \\
\hline B. cereus & 14 & 28 \\
\hline B. coagulans & 9 & 18 \\
\hline B. stearothermophilus & 6 & 12 \\
\hline B. subtilis & 11 & 22 \\
\hline B. megaterium & 3 & 6 \\
\hline
\end{tabular}

Table 3: Statistical analytical results of $\mathrm{Cl}$. Perfingens count/g of the examined condensed milk samples using MPN technique.

\begin{tabular}{|c|c|c|c|c|c|}
\hline $\begin{array}{c}\text { No. of } \\
\text { examined } \\
\text { samples }\end{array}$ & $\begin{array}{c}\text { Positive } \\
\text { samples }\end{array}$ & \multicolumn{4}{|c|}{ Count/g } \\
\cline { 2 - 6 } & No. & $\%$ & Min. & Max. & Average \\
\hline 50 & 3 & 6 & 3.0 & $7.5 \times 10^{1}$ & $2.9 \times 10^{1}$ \\
\hline
\end{tabular}

Table 4: Statistical analytical results of $\mathrm{Cl}$. perfringens count $/ \mathrm{g}$ of the examined condensed milk samples using direct plating technique.

\begin{tabular}{|c|c|c|c|c|c|}
\hline \multirow{2}{*}{$\begin{array}{c}\text { No. of } \\
\text { examined } \\
\text { samples }\end{array}$} & \multicolumn{2}{|c|}{$\begin{array}{c}\text { Positive } \\
\text { samples }\end{array}$} & \multicolumn{4}{|c|}{ Count/g } \\
\cline { 2 - 6 } & No. & $\%$ & Min. & Max. & Average \\
\hline 50 & 2 & 4 & $1.0 \times 10^{2}$ & $2.0 \times 10^{2}$ & $1.5 \times 10^{2}$ \\
\hline
\end{tabular}


1ssiul Vet. Med.J. Vol. $45 \mathrm{No}$.90.Julv 2001

Table 5: Statistical analytical results of thermophilic fungi count $/ \mathrm{g}$ of the examined condensed milk samples.

\begin{tabular}{|c|c|c|c|c|c|}
\hline \multirow{2}{*}{$\begin{array}{c}\text { No. of } \\
\text { examined } \\
\text { samples }\end{array}$} & \multicolumn{2}{|c|}{$\begin{array}{c}\text { Positive } \\
\text { samples }\end{array}$} & \multicolumn{3}{c|}{ Count/g } \\
\cline { 2 - 6 } & No. & $\%$ & Min. & Max. & Average \\
\hline 50 & 3 & 6 & $1.0 \times 10^{2}$ & $4.0 \times 10^{3}$ & $1.6 \times 10^{3}$ \\
\hline
\end{tabular}

\section{DISCUSSION}

Results reported in Table 1 revealed that $62 \%$ of the examined condensed milk samples contained thermoduric bacteria, with an average count of $7.6 \times 10^{3} / \mathrm{g}$. Likewise, B. cercus, B. coagulans, B. stearothermophilus, B, subtilis and B. megaterium could be isolated from the examined condensed milk samples with incidence percentages of 28 , $18,12,22$ and $6 \%$, respectively (Table 2). On the other hand, Ahmed et al. (1988) could not detect B. cereus from the examined samples of condensed milk. Sweetened condensed milk is not a sterile product and the sugar acts as a preservative. Heat-resistant organisms, such as aerobic sporeforming bacteria may at times survive the heat treatment (Crossley and Craham, 1966 and Lampert, 1987). The main source of contamination of condensed milk by these microorganisms may be from imperfectly cleaned machinery and incompletely sterilized tins (Garcia, 1959). A general risk due to post-processing contamination, of course, exist with non-sterile products, while sterilized concentrated milk is subjected to the same risks as all canned foods with respect to underprocessing and seam leakage (Varnam and Sutherland, 1994). It is worthwhile to state that B, cereus was capable to cause off llavours of milk products such as unclean, fruity, bitter, putrid, rancid and yeasty (Stadhouders, 1993). Also, other aerobic sporeforming bacteria such as B. coagulans and B. stearothermophilus can cause an acid coagulation with a slight cheesy odour and flavour. B. subtilis causes a non-acid curd, which can result in a brownish liquid with a bitter taste. The coagulum formed by B. megaterium is accompanied by some gas and a cheesy odour (ICMSF, 1980; Nelson, 1990 and Milner, 1995). Furthermore, B. cereus is recognized as one of the potential organisms for human food poisoning (Iversen et al., 1982; Christiansson, 1992 and Granum et al., 1993) 
The results outlined in Table 3 indicated that the incidence of $\mathrm{Cl}$. perfringens in the condensed milk samples was $6 \%$ by applying lactose sulphite (LS) broth, with an average of $2.9 \times 10^{1} / \mathrm{g}$. The LS broth gives a good selectivity which allows the detection of low numbers of $\mathrm{Cl}$. perfringens in the presence of other sulphite-reducing bacteria. Confirmatory tests not required and the senstivity of the medium is the most important advantage of this procedure. Also, by plating on SPS agar, the occurrence percentage of $\mathrm{Cl}$. perfringens was low $(4 \%)$ in the examined condensed milk samples, with an average value of $1.5 \times 10^{2} / \mathrm{g}$ (Table 4). The thermal processing of condensed milk had an effect on lowering the incidence $\%$ and the count of $\mathrm{Cl}$. perfringens. The obtained results agree to a certain extent with those reported by Ahmed et al. (1988). The incidence of $\mathrm{Cl}$. perfringens in sweetened condensed milk has also been studied by Bhale ct al. (1989) and Milner (1995). This work indicates the potential microbiological problems associated with this type of canned milk. Likewise, Fujisawa et al. (2000) suggested that the use of enrichment methods for detection of clostridia is essential. Moreover, $\mathrm{Cl}$. perfringens is responsible for a considerable number of food poisoning outbreaks annually. From 1985 to 1989 , Cl. perfringens food poisoning constituted $21.2,18,12.2,9.1,8,7,7$ and $5.4 \%$ of the total food poisoning outbreaks in Finland, Switzerland, Denemark, Netherland, United Kingdom, France, Iceland and Germany, respectively (Anon, 1990).

The achieved results recorded in Table 5 show that thermophilic fungi could be detected in $6 \%$ of the examined condensed milk samples with an average number of $1.6 \times 10^{3} / \mathrm{g}$. A higher incidence and lower counts of fungi were observed in condensed milk examined by Ahmed et al. (1988). Yeasts and moulds could be isolated from such product by Rao and Ranganathan (1970) and Sallam (1979). Generally, condensed milks are favourable media for the growth of a wide range of environmental contaminants. Canned sweetened condensed milk with its high sugar content may swell occasionally owing to growth of yeasts (Tudor and Board, 1993). If the can is underfilled, however, the large head space may allow enough oxygen for mould growth to occur on the product surface. Moulds may also have entered the product between the pasteurizer and the can-closing machine through a defective seam or pinhole, or contamination can arise from filling equipment and nonsterile cans. Mould growth often occurs as buttons i.e. small areas of mycelial gorwth on the surface of the stored product. The moulds most 
likely to be present are Aspergillus and Penicillium (ICMSF, 1980: Varnam and Sutherland, 1994 and Milner, 1995). Concerning, the public health significance and the pathogenesis of mycotoxins, it is well known that in many cases potential problems involve the possibility of cancer or delayed organ damage due to repeated ingestion of subacute levels. Certain foodborne yeasts and moulds may be hazardous because of their ability to elicit allergic reactions. Aflatoxin $\mathrm{M}_{1}$ is highly toxic, mutagenic, teratogenic and carcinogenic compound that have been implicated as causative agent in human hepatic and extrahepatic carcinogens (Mislivec et al., 1992; Massey et al., 1995; Markaki and Melissari, 1997 and Li ct al.,., 2000).

In conclusion, using high quality raw milk and sugar in condensed milk manufacture, good sanitation and hygiene during production, handling and storage of such product are important to prevent the condensed milk from spoilage and to protect the consumers from infection. Also, a high standard of plant hygiene is needed to avoid postprocessing contamination. However, the heat treatments used in production of condensed milk are insufficient to sterilize the product, so strict hygienic measures are still required. In addition, the viscous nature of this product needs to be taken into account for the cleaning procedures. Finally, employment of experienced staft is necessary at all times.

\section{REFERENCES}

A.P.H.A. (American Public Health Association) (1992): Compendium of methods for the microbiological examination of foods. $3^{\text {td }} \mathrm{Ed}$. American Public Health Association, Washington, D.C., USA.

Ahmed, A.A-H.; El-Bassiony, T.A. and Moustafa, M.K. (1988): Microbiological evaluation of condensed milk. Assiut Vet. Med. J. 20: 98-102.

Angelotti, R.; Hall, H.E.; Foster, M.J. and Lewis, K.H. (1962): Quantitation of Clostridium perfringens in foods. Appl. Microbiol. 10: 193-199

Anon (1990): FAO / WHO, News letter, Robert Von Ostertag Institute, Berlin. 
Beerens, H.: Romond, C.: Lepage, C. and Griquelion, J. (1982): A liquid medium for the enumeration of Clostridim in food and faeces. In. Isomeration of Clostridium perfringens food poisoning organisms, and identification methods for F.A. Skinner, Academic Pross, I b. J. Corry; D. Roberts and Thate. Skinner, Academic Press, I.ondon, PP. 137-149. condensed, S. and Sinha, R.N. (1989): Clostridia in sweetened Food Sci. Technol 26:46-48. associated deteriorative changes. J. . Technol. 26: 46-48.

Christiansson, A. (1992): The toxicology of Bacillus cereus in milk and milk products. Bulletin IDF. 275: 30-35.

Crossley, E.L. and Craham, P.A. (1966): Microbiological changes during the storage of sweetened condensed milk, XVI International Dairy Congress, Sec. E/3, 167, Munich.

Fujisawa, T.; Aikawa, K.; Furukawa, 1. and Takahashi, T. (2000). Occurrence of clostridia in glass bottled foods. Int. J. Food Microbiol. 54: 213-217

Garcia, F.R. (1959): Microbiological control of the manufacture of condensed milk. Dairy Sci. Abs. 24, 256 (1962).

Granum, P.E.; Brynestad, S.; Sulivan, K.O. and Nissen, H. (1993). Enterotoxin from Bacillus cereus production and characterization. Nether. Milk and Dairy J. 47: 63-70.

I.C.M.S.F. (International Commission on Microbiological Specifications for Food) (1980): Microbial ecology of foods. Vol, 2: Food commodities. London: Academic Press.

Iversen, $H_{\text {; }}$ Rosef, $O$. and Selas, $P$. (1982): Outbreak of food poisoning caused by Bacillus cereus at a geriatric and health care centre, Norsk-Veterinaertidskrift. 94: $337-340$

Kramer, J.M.; Turnbull, P.C; Munshi, G. and Gilbert, R.J. (1982) Identification and characterization of Bacillus cereus and other Bacillus species associated with food poisoning. In: Isolation and Identification Methods for Food Poisoning Organisms, Corry, J.E.; Roberts, D. and Skinner, F.A. (Eds). Academic Press. London and New York. Lampert, L.M. (1987): Modern Dairy Products. Lurasia Publishing
House (Pvt) LTD.

Lit S.; Marquardt, R.R. and Abramson, D. (2000): Immunochemical detection of molds: A review. J. Food Prot. 63: 281-291. 
Markaki, P. and Melissari, E. (I997): Occurrence of aflatoxin M in commercial pasteurized milk determined with FLISA and HPLC. Food Addit. Contam. 5: 451-456.

Masscy. T.E.: Stewart, R.K: Laniel, J.M. and Ling, L. (1995): Biochemimammalian susceptability to aflatoxin $B_{1}$ carcinogenicity. Proceed. Soc. Exp. Biol. Med. 208: 213-227.

Mead. (i.C.; Paezdeleon, L. and Adams, B.W. (1981): A study of rapid and simplified confirmatory tests for Clostridium perfringens. J. Appl. Bacteriol. 51:355-361.

Milner, J. (1995): Microbiology Handbook. I.eatherhead Food RA. Randalls Road, Leatherhead, Surrey KT 22 7RY.

Mislivec, P.B.: Betuchat, L.R. and Cousin, M.A. (1992): Yeasts and Molds. Chapter 16. Compendium of Methods for Microbiological Examination of Foods. $3^{\text {rd }} \mathrm{Fd}$. American Public Health Association, Washington, DC.

Nelson. F.E. (1990): The microbiology of concentrated milks. Dairy microbiology. Vol. 1: The microbiology of milk products. Ed. R.K. Robinson. London: Elsevier Applicd Science Publishers.

Parry, J.M.; Turnbull, P.C. and Gibson, J.R. (1983): A Colour Atlas of Bacillus Species. Wolfc Medical Publications Ltd. London.

Rao, V.J. and Ranganathan (1970): Studies on the microbiology of swcetened condensed milk. Indian J. Dairy Sci. 23: 205.

Sallam, S.S. (1979): Microbiological investigation of powdered and condensed milk. M.V.Sc. Thesis. Fac. Vet. Med., Cairo Univ, Egypt.

Speck. M.l. (ed) (1976): Compendium of methods for microbiological examination of food. American Public Health Association, Washington, DC.

Stadhouders, J. (1993): Bacillus cereus in milk and milk products. Bulletin of the International Dairy Federation. No. 287: 3-5.

Tudor, F.A. and Board, R.G. (1993): Food-spoilage yeasts. The yeasts. Vol. 5: Yeast technology. Eds A.H. Rose \& J.S. Harrison. $2^{\text {nd }}$ Ed. London: Academic Press: 435-516.

Varnam, A.II. and Sutherland, J.P. (1994): Milk and Milk Products: lcchnology, Chemistry and Microbiology. Chapman and Hall. London, UK. 